\title{
Three strains of bean yellow mosaic virus: symptoms and accumulation in eight pea cultivars (Pisum sativum $\mathbf{L}$.)
}

\author{
JARI P.T. VALKONEN
}

\begin{abstract}
VALKONEN, J.P.T. 1993. Three strains of bean yellow mosaic virus: symptoms and accumulation in eight pea cultivars (Pisum sativum L.). Agric. Sci. Finl. 2: 41-49. (Dept. PI. Product., FIN-00014 Univ. Helsinki, Finland.)

A pea mosaic strain and a bean strain of bean yellow mosaic virus (BYMV) were isolated from naturally infected pea and broad bean plants and named BYMV-Ps and BYMV-Vf, respectively. A third strain of BYMV isolated from Gladiolus (BYMV-G) was obtained from Denmark which was distinguished from the two above strains serologically and by its symptoms in test plants.

BYMV-Ps and BYMV-Vf caused yellow mosaic symptoms and green mosaic symptoms, respectively, in eight pea cultivars tested, but the concentration of BYMV varied among the cultivars. BYMV-G caused mild mosaic or vein clearing in peas. A need to improve resistance to BYMV in the Finnish pea varieties was recognized.
\end{abstract}

Key words: BYMV, broad bean, virus resistance

\section{Introduction}

Bean yellow mosaic potyvirus (BYMV) occurs worldwide and infects several economically important legumes, including peas (Pisum sativum L.), beans (Phaseolus spp.) and broad beans (Vicia faba L.) and non-leguminous plant species, such as those in the family Iridaceae and the genus Fagus. In legumes, BYMV is transmitted by several species of aphids in a non-persistent manner, and also experimentally in sap of infected plants (BoS 1970a, TAPIO 1970, COCKBAIN 1983, HAMPTON 1984, JAYASENA and RANDLES 1985, BAYS and DEMSKI 1986, WINTER and NIENHAUS 1989, PROVVIDENTI 1991). Many strains of BYMV have been reported which may be distinguished by host range, aphid transmission, serology or RNA sequence heterology (BOS 1970a, JONES and DIACHUN 1977, REDDICK and BARNETT 1983, SCHMIDT and ZOBYWALSKI 1984, HERRERA and SEPULVEDA 1986,
BARNETT et al. 1987, SCOTT et al. 1989, HOPPS and MCLAUGHLIN 1990). The pea strain of BYMV, formerly considered a distinct virus from the bean strain of BYMV and called pea mosaic virus (PMV), causes bright yellow mosaic symptoms, whereas the bean strain of BYMV causes green mosaic symptoms in pea leaves (Bos 1970b, TAPIO 1970). Both strains of BYMV infect broad beans inducing similar symptoms and cytoplasmic and nuclear inclusions (BOS 1969, TAPIO 1970, COCKBAIN 1983). The bean and pea strains of BYMV occur naturally in Finland, and these strains may cause a yield loss of up to $62 \%$ and $30 \%$, respectively, in peas depending upon the age at which the plants are infected (TAPIO 1970). BYMV has been observed to infect broad bean in the field in Finland in the 1970s (A. Kurppa, pers. com.).

Pea breeding programmes in Finland have been successful in increasing the protein content of peas and developing high-yielding semileafless (afila- 
pea) varieties. Several new afila-pea varieties have been released by the Anttila Plant Breeding Farm (APBF) (formerly Hankkija Plant Breeding Institute) during the last decade. Many of them are cultivated or included in official variety testing programmes in other countries, e.g. Sweden, Norway, Denmark, Canada and Estonia (KuJALA 1953, KIELPINSKI and BLIXT 1982, HOVINEN 1988, S. HOVINEN pers. com.). However, breeding for resistance to viruses was not particularly emphasized, and only resistance to pea seed-borne mosaic virus has been incorporated into a few breeding lines (HovinEN 1990). Pea plants with yellow mosaic symptoms are commonly found in experimental fields of APBF (S. HovinEN pers. com.). In the present study, two strains of BYMV were isolated from naturally infected pea and broad bean plants. Eight pea cultivars were inoculated with the above Finnish BYMV isolates and one Danish BYMV isolate. These cultivars included some of the recently released varieties of APBF as well as one old Finnish and two Dutch cultivars commonly grown in Finland. The objective was to determine whether any resistance to BYMV from foreign genetic materials had been incorporated into new pea varieties by breeders in addition to the characters being deliberately selected.

\section{Material and Methods}

\section{Plants and growing conditions}

The following pea cultivars released by APBF were included in the experiments: Helka (Proco x Hja 51221), afila-type, released in 1986; Hemmo (Maro x Kalle), leaflet-type, released in 1980; Hovi (Filby x Heikka), afila-type, released in 1989; Kalle (Torstai x Folger), leaflet-type, released in 1952; Pika (Proco x Tammi), afila-type, released in 1986; and Tammi (Simo x Usatyj 5), afila-type, released in 1984. The Dutch leaflet-type cv. Proco and afilatype cv. Solara widely grown in Finland were also included.

Experiments were done in a screenhouse and a glasshouse under natural daylight at the University of Helsinki, Viikki $\left(60^{\circ} 13^{\prime} \mathrm{N}\right)$ during August -
mid-September in 1992. Seeds were sown into a mixture of steam-sterilized peat and washed sand $(10: 1 \mathrm{v} / \mathrm{v})$, and the plants were watered daily with a solution containing $0.1 \%$ NPK fertilizer (5-7-6). Plants in the screenhouse were sprayed weekly with dimethoate, and the glasshouse was fumigated weekly with nicotine to prevent any contamination by aphids. Daily means of the minimum and maximum temperatures were $10^{\circ} \mathrm{C}$ and $19^{\circ} \mathrm{C}$ in the screenhouse and $16^{\circ} \mathrm{C}$ and $28^{\circ} \mathrm{C}$ in the glasshouse.

\section{Viruses}

To obtain isolates of BYMV, leaves of pea and broad bean plants showing yellow and green mosaic symptoms were sampled in the experimental fields of the Anttila Plant Breeding Farm $\left(60^{\circ} 25^{\prime} \mathrm{N}\right)$ on July 28, 1992. Batches of c. $20-100$ plants with bright yellow mosaic symptoms were found scattered in many pea fields (Fig. 1), and all the samples from those plants reacted strongly when tested in DAS-ELISA with the two antisera available to BYMV. The virus isolate from the pea breeding line $\mathrm{Hja} 57839$ which gave the highest ELISA absorbance values was selected for further studies and named BYMV-Ps. Similarly, the virus isolate from the broad bean breeding line $\mathrm{Hja}$ 62029A, which produced the highest ELISA absorbance values for BYMV, was used in further experiments and named BYMV-Vf. One isolate of BYMV obtained from Gladiolus in Denmark by Dr. N. Paludan (isolate DK-17-3-4: BOYE et al. 1990, ALBRECHTSEN et al. 1991) was kindly provided in freeze-dried leaves of Nicotiana benthamiana Domin. by Dr. M. Albrechtsen, Danish Research Center for Plant Protection, Lyngby, Denmark, and this is referred to as BYMV-G. BYMV-Ps and BYMV-G were maintained in the pea cv. Kalle, and BYMV-Vf was maintained in the broad bean cv. Ukko.

\section{Antisera}

Polyclonal antibodies raised in rabbits against BYMV-G and alkaline phosphatase (AP) conjugated antibodies were kindly supplied by Dr. M. 


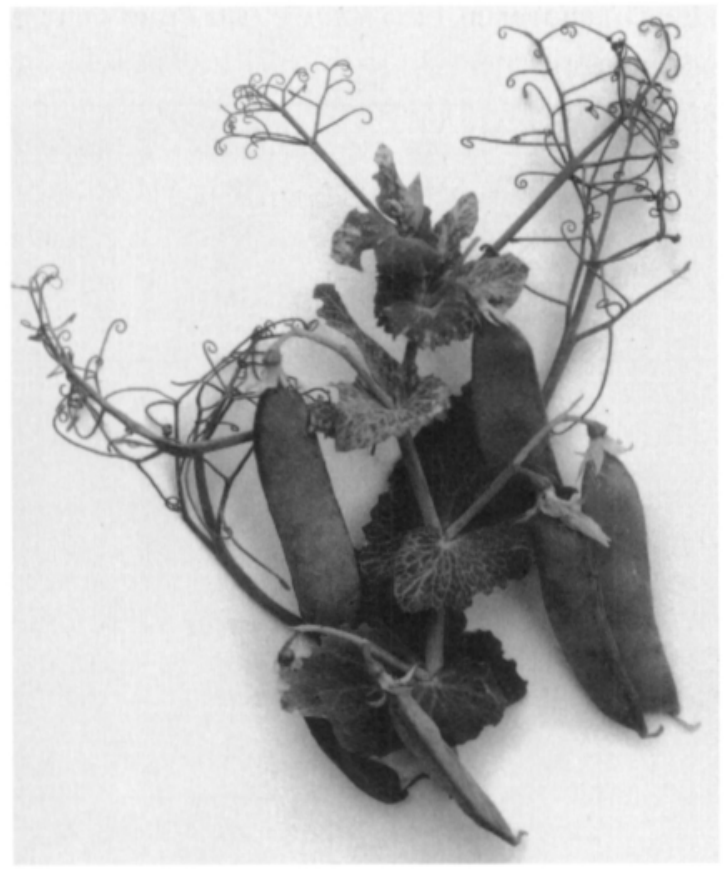

Fig. 1. A pea plant (breeding line $\mathrm{Hja}$ 57839) naturally infected with BYMV-Ps collected from the experimental fields of APBF.

Albrechtsen, and were used in all serological tests. Rabbit polyclonal antibodies (ATCC PVAS-368 4-85) to BYMV (HAMMOND and HAMMOND 1989) were obtained from the American Type Culture Collection (ATCC), Rockville, USA, and conjugated with AP at our laboratory. The BYMV antibodies from M. Albrechtsen and ATCC were used in parallel ELISA tests for the detection of BYMV in the field samples.

\section{Inoculations}

BYMV was sap-inoculated by grinding $1 \mathrm{~g}$ of BYMV-infected leaves in $5 \mathrm{ml}$ of $0.001 \mathrm{M}$ phosphate buffer, $\mathrm{pH}=7.5$, and rubbing the sap onto carborundum-dusted stipules of pea seedlings and leaves of the other test plant species when the plants were 10 days old. Four plants each of the eight pea varieties and test plant species were inoculated with each of the three virus isolates in two replicate experiments.

\section{Virus detection}

BYMV was detected by double antibody sandwich enzyme-linked immunosorbent assay (DASELISA) (CLARK 1981) and by immunosorbent electron microscopy (ISEM) (ROBERTS and HARRISON 1979). Stipules or leaves of the three uppermost knots of the pea plants and the uppermost fully-expanded leaves of the other test plant species were sampled in duplicate. Samples were weighed and ground in four volumes $(\mathrm{w} / \mathrm{v})$ of extraction buffer for DAS-ELISA and in nine volumes $(\mathrm{w} / \mathrm{v})$ of $0.06 \mathrm{M}$ phosphate buffer, $\mathrm{pH}=6.5$, for ISEM. In DAS-ELISA, the absorbances were recorded at 405 $\mathrm{nm}\left(\mathrm{A}_{405}\right)$ using the ELISA reader (Titertek Multiscan) after 45 min of incubation with the substrate p-nitrophenyl. Inclusion bodies of BYMV were stained by immersing epidermal strips from the undersides of leaves of $V$. faba cv. Ukko in a solution containing $0.5 \%$ Trypan blue and $0.9 \% \mathrm{NaCl}$.

\section{Statistical analysis}

Analysis of variance was used for statistical analysis, and calculations of the least significant differences (LSD) of the A405 values were made where appropriate (STEEL and TORRIE 1981).

\section{Results}

The isolates BYMV-G, BYMV-Vf and BYMV-Ps were distinguished by the symptoms they caused in test plants (Table 1). In all the pea cultivars tested, BYMV-Ps caused bright yellow mosaic symptoms, whereas BYMV-Vf caused mainly green mosaic and sometimes mild yellow mosaic symptoms (Fig. 2 ). However, BYMV-G caused only very mild mosaic symptoms and vein clearing. Similarly, BYMV-Vf and BYMV-Ps caused severe green mosaic symptoms in the broad bean cv. Ukko, and the symptoms of BYMV-Vf were visible sooner than those of BYMV-Ps. In contrast, broad bean plants infected with BYMV-G became slightly pale and showed no other symptoms. BYMV-Vf and BYMV-Ps infected Trifolium pratense cv. Bjursele 
Table 1. Symptoms in test plants caused by isolates of BYMV from Gladiolus (G), Vicia faba (Vf) and Pisum sativum (Ps).

\begin{tabular}{llll}
\hline & BYMV-G & BYMV-Vf & BYMV-Ps \\
\hline Phaseolus vulgaris cv. Dufrix & LRSr, LVN, SM, St & SRSg, SM, St & SRSg, SM, St \\
Nicotiana benthamiana & MM/ SSI & SM & SM \\
Pisum sativum & MM, VCl & GM & YM \\
Vicia faba cv. Ukko & SSI & GM & GM \\
Chenopodium amaranticolor & LL & - & LL \\
\hline
\end{tabular}

$\mathrm{LL} \quad=$ local lesions

$\mathrm{LRSr}=$ local ring spots with red margins

$\mathrm{LVN}=$ local vein necrosis

$\mathrm{GM}=$ green mosaic

$\mathrm{SM}=$ systemic mosaic

$\mathrm{YM}=$ yellow mosaic

SRSg $=$ systemic ring spots with green margins

SSI = systemic symptomless infection detected by ELISA

$\mathrm{St} \quad=$ stunting

$\mathrm{VCl}=$ vein clearing

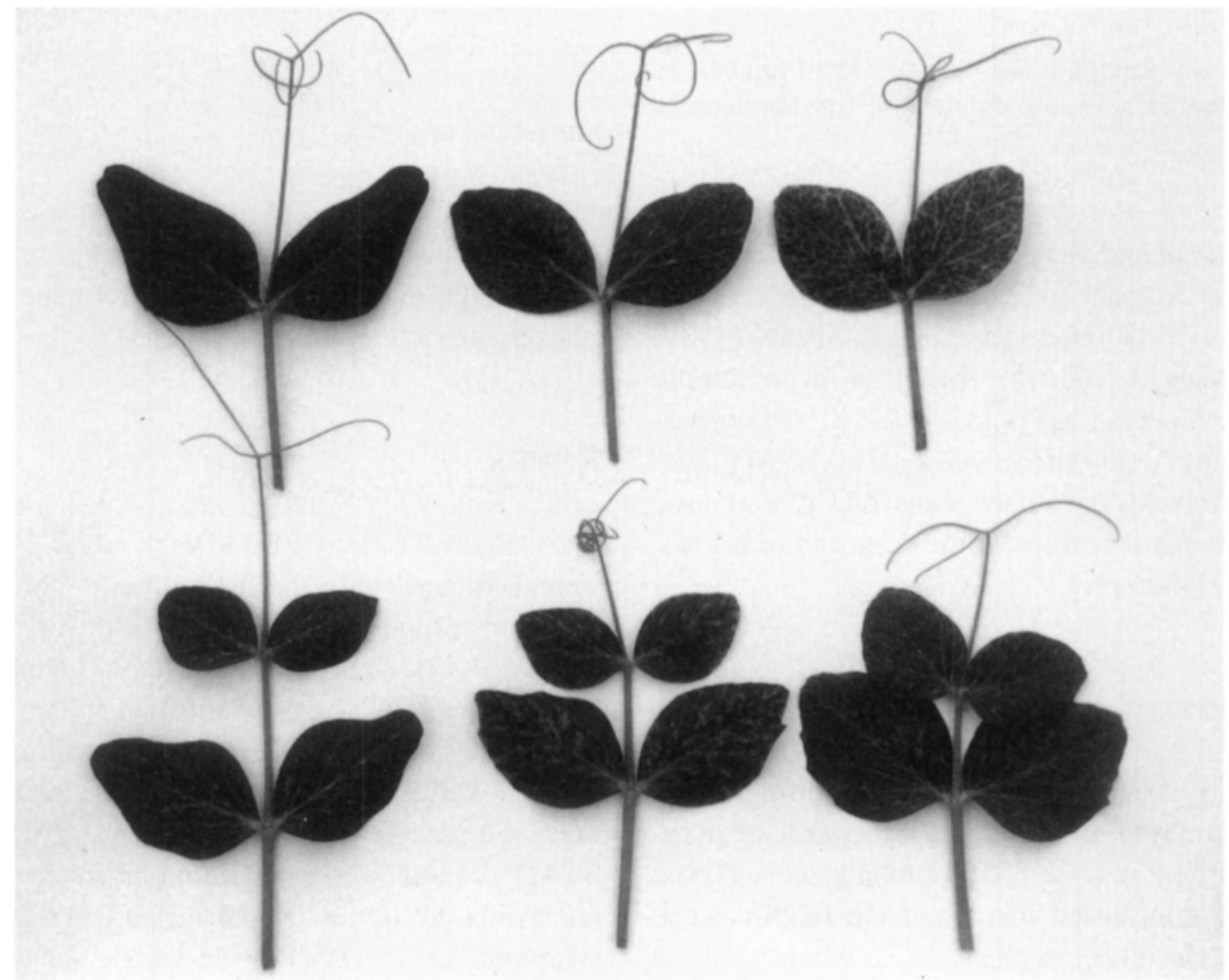

Fig. 2. Leaves of the pea cvs. Proco (upper row) and Hemmo (lower row) systemically infected with BYMV-Ps (right) showing yellow mosaic symptoms, and with BYMV-Vf (middle) showing green mosaic symptoms following sap-inoculation (on the left: leaves from non-inoculated plants). 
Table 2. Mean absorbance values from ELISA for detection of BYMV in plants each of eight pea cultivars grown in a screenhouse (a) and glasshouse (b) and also in $P$. vulgaris cv. Dufrix grown in a glasshouse (b) 18 days post-inoculation. The BYMV isolates were from Gladiolus $(\mathrm{G})$, Vicia faba $(\mathrm{Vf})$ and Pisum sativum (Ps). The least significant differences are given at the risk level of $1 \%\left(\mathrm{LSD}_{0.01}\right)$.

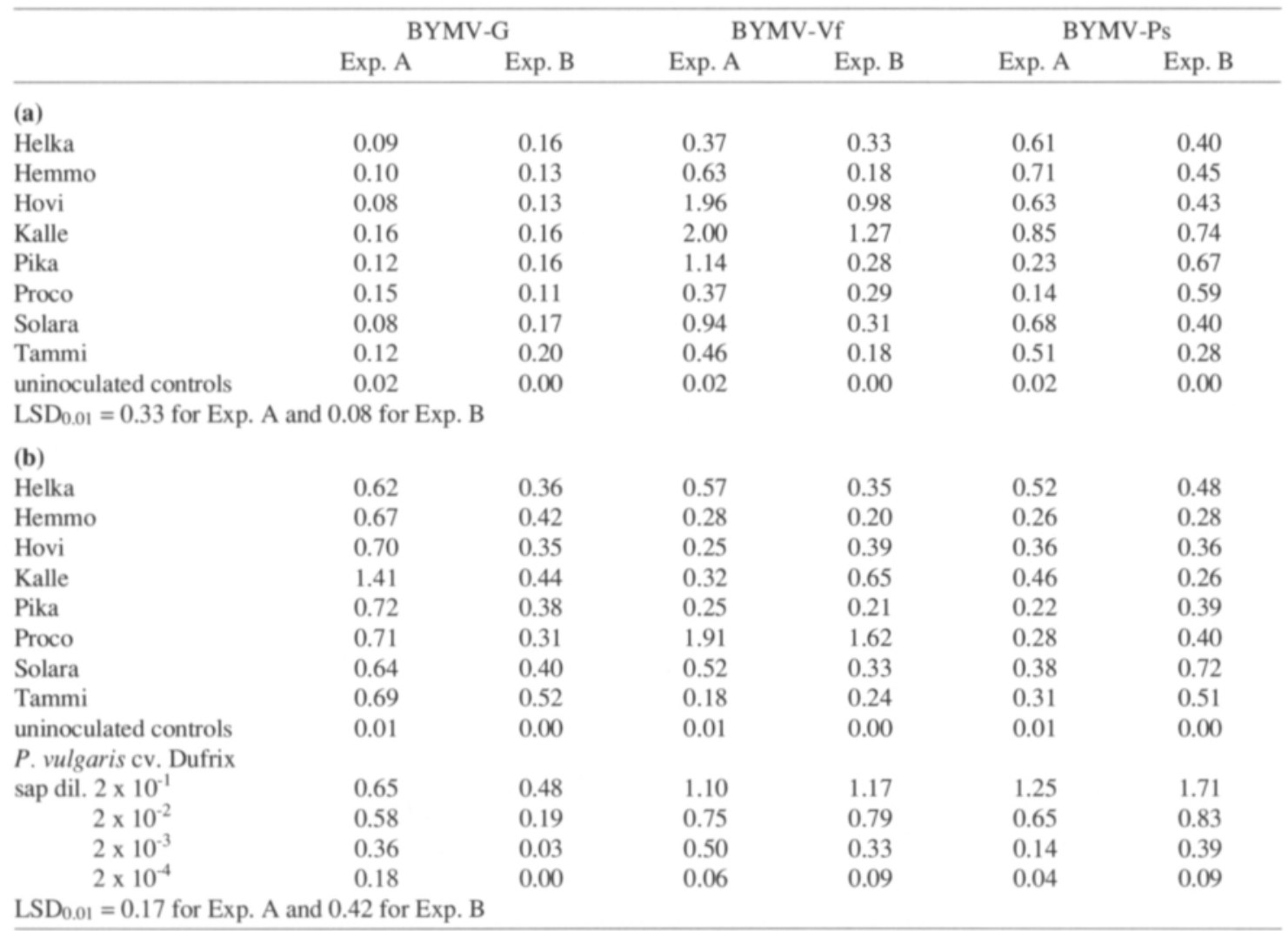

causing systemic vein chlorosis and yellowing, but no infection with BYMV-G was detected. The leaves of $P$. vulgaris L. cv. Dufrix inoculated with BYMV-G produced local ringspots and vein necrosis, but those inoculated with BYMV-Vf or BYMV-Ps remained symptomless. All the BYMV isolates infected Lupinus luteus L. causing systemic green mosaic symptoms, narrowing of leaflets and severe stunting. In Nicotiana tabacum L. cv. Samsun, all the BYMV isolates caused local symptomless infection which was detected by ELISA, but no systemic infection.

The mean lengths of 50 particles of the BYMVG, BYMV-Vf and BYMVPs isolates were $781 \mathrm{~nm}$, $778 \mathrm{~nm}$ and $816 \mathrm{~nm}$, respectively, in sap prepared for ISEM from systemically infected leaves of $P$. vulgaris cv. Dufrix. Morphologically identical intranuclear inclusion bodies were detected in the epidermic cells of BYMV-infected $V$. faba cv. Ukko with all the BYMV isolates (Fig. 3).

The A405 values for the detection of BYMV-Vf and BYMV-Ps differed significantly between many pea cultivars (Table 2). However, symptoms among the cultivars infected with BYMV-Vf or BYMVPs were similar. Thus, the virus titres did not correlate with the severity of symptoms. The concentration of BYMV-G was clearly increased, whereas the concentration of BYMV-Ps was slightly depressed, in pea plants grown in the higher glasshouse temperatures compared to plants grown in the cool screenhouse. In most of the plant species tested, the A405 values from ELISA for the detection of 


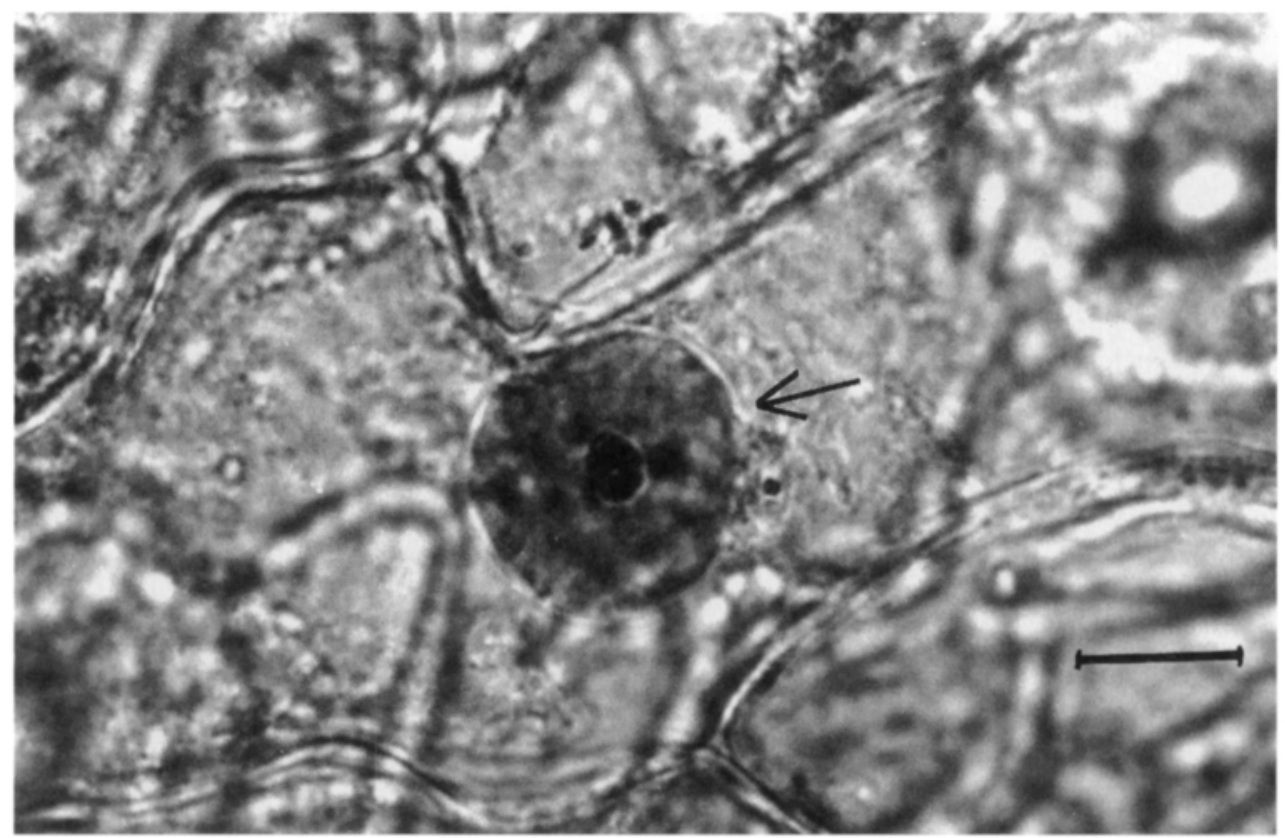

Fig. 3. An intensely stained enlargened nucleolus containing granular inclusion bodies in a weaker stained nucleus (arrow) in an epidermic cell of $V$. faba cv. Ukko systemically infected with BYMV-Vf (bar $=10 \mu \mathrm{m})$.

BYMV-G were lower than those for the other two BYMV isolates. However, sap-inoculation of BYMV-G and BYMV-Ps from L. luteus, pea cv. Kalle and $P$. vulgaris cv. Dufrix to $C$. amaranticolor Coste et Reyn resulted in similar numbers of local lesions, indicating that the titres of infective virus were similar.

\section{Discussion}

The isolates BYMV-G, BYMV-Vf and BYMV-Ps were clearly distinguished from each other by the symptoms they caused in various test plant species. The symptoms in pea plants and the slightly longer particles of the BYMV-Ps isolate were similar to those of the pea mosaic strains of BYMV previously described, and the symptoms caused by BYMV-Vf in the test plants resembled those described for the bean strain of BYMV (Bos 1970a,b, TAPIO 1970). As with other potyviruses, the length of BYMV particles in plant extracts is affected by the concentration of magnesium ions in the extraction buffer (Govier and WoODS 1971). On the other hand, BYMV-G differed from the other two BYMV isolates by its milder symptoms in most of the test plant species, and also serologically, as has been reported previously for other BYMV isolates (JONES and DIACHUN 1977). However, all the isolates reacted with the antibodies raised against BYMV (obtained from M. Albrechtsen and ATCC), but not with those raised against bean common mosaic virus (obtained from L. Bos and D.Z. Maat, Institute for Phytopathological Research (IPO), Wageningen, The Netherlands; data not shown). The intranuclear inclusion bodies produced by all the virus isolates were identical and similar to those previously described for BYMV (BOS 1969, CHANG et al. 1988). Therefore, all the virus isolates represented distinct strains of a single virus species, namely BYMV.

All the recently released pea cultivars of APBF included in the present study were susceptible to BYMV, suggesting that little or no improvement in resistance to BYMV has occured during the last decades and since the previous studies by TAPIO (1970). However, yield losses caused by BYMV in pea are potentially high in Finland, and the virus is 
readily spread by aphids from forage legumes to peas in the field, red clover acting as the main virus reservoir (TAPIO 1970). Globally, BYMV is considered one of the most important pathogens of pea, particularly in older cultivars lacking resistance to BYMV (HAMPTON 1984). Aphicides are ineffective in decreasing the spread of the nonpersistently transmitted viruses such as BYMV, but treatment of plants with mineral oil may be more successful (COCKBAIN 1983, JAYASENA and RANDLES 1985). However, resistance to BYMV in pea remains to be developed for virus control in the field. Indeed, since 1965 the recessive gene pair mo/mo conferring resistance to BYMV in $P$. sativum has been routinely incorporated into new pea cultivars in many pea breeding programmes abroad, which is the primary reason to consider BYMV as a minor pathogen of pea at the present (MARX and PROVVI-
DENTI 1979, HAMPTON 1984). As the domestic cultivation of pea is limited in Finland (7700 ha in 1990, HovineN 1990), breeding of peas in Finland should meet the requirements of an international market area to strengthen the economic basis of the breeding programme. Lack of resistance to viruses may be one of the obstacles reducing the adaptability of Finnish pea varieties for cultivation abroad. Genetically engineered virus resistance, such as coat protein mediated resistance to BYMV, is also becoming available in peas in the future (HAMMOND and KAMO 1991, CECCHINI et al. 1992, HULL and DAVIES 1992).

Acknowledgements. I am most grateful to Dr. Simo Hovinen for information on the Pea Breeding Programme of APBF, and to S. Hakola and R.N.P. Vili for assistance in the collection of samples from the field.

\section{References}

Albrechtsen, M., Paludan, N. \& Heide, M. 1991. Differentiation of potyviruses through peptide mapping of cytoplasmic inclusion proteins. J. Phytopathol. 131: 227-233.

Barnett, O. W., Randles, W. J. \& Burrows, P. M. 1987. Relationships among Australian and North American isolates of bean yellow mosaic potyvirus subgroup. Phytopathology 77: 791-799.

BAYS, D. C. \& DEMSKI, J. W. 1986. Bean yellow mosaic virus isolate that infects peanut (Arachis hypogaea). Pl. Dis. 70: 667669 .

Bos, L. 1969. Inclusion bodies of bean yellow mosaic virus, some less known closely related viruses and beet mosaic virus. Neth. J. PI. Pathol. 75: 137-143.

- 1970a. Bean yellow mosaic virus. C.M.I./A.A.B. Descriptions of Plant Viruses No. 40. Commonwealth Mycol. Inst. Assoc. Appl. Biol., Surrey, UK.

- 1970b. The identification of three new viruses isolated from Wisteria and Pisum in The Netherlands, and the problem of variation within the potato virus $\mathrm{Y}$ group. Neth. J. Pl. Pathol. 76: 8-46.

Boye, K., Jensen, P. E., Stummann, B. M. \& Henningsen, K. W. 1990. Nucleotide sequence of cDNA encoding the BYMV coat protein gene. Nucleic Acids Res. 18: 4926.

Cecchini, E., Natali, L., Cavallini, A. \& Durante, M. 1992. DNA variations in regenerated plants of pea (Pisum sativum L.). Theor. Appl. Genet. 84: 874-879.

Chang, C.-A., Hiebert, E. \& Purcifull, D. E. 1988. Purification, characterization and immunological analysis of nuclear inclusions induced by bean yellow mosaic and clover yellow vein potyviruses. Phytopathology 78: 1266-1275.

Clark, M. F. 1981. Immunosorbent assays in plant pathology. Ann. Rev. Pl. Pathol. 19: 83-106.

Cockbain, A. J. 1983. Viruses and virus-like diseases of Vicia faba L. In: Hebbelwaite, P.H. (ed.). The Faba Bean (Vicia faba L.). Butterworths, London, UK. p. 421-462.

Govier, D. A. \& Woods, R. D. 1971. Changes induced by magnesium ions in the morphology of some plant viruses with filamentous particles. J. Gen. Virol. 13: 127-132.

Hammond, J. \& Hammond, R. W. 1989. Molecular cloning, sequencing and expression in Eschericia coli of the bean yellow mosaic virus coat protein gene. J. Gen. Virol. 70: 1961-1974.

— \& Kamo, K. K. 1991. Potyviral antisense RNA or coat protein in transgenic Nicotiana benthamiana. Intern. Soc. Pl. Mol. Biol. 3rd Intern. Cong. Abst. no. 1142.

Hampton, R. O. 1984. Pea mosaic. In: Hagedorn, D.J. (ed.). Compendium of Pea Diseases. Am. Phytopathol. Soc., St. Paul, USA. p. 37.

Herrera, G. G. \& Sepulveda, R. P. 1986. Determinacion de una nueva raza del virus del mosaico amarillo del frejol en Chile. Agricultura Tecnica 46: 137-142.

Hopps, H. A. \& Mclaughlin, M. R. 1990. A non-aphid transmissible isolate of bean yellow mosaic virus Scott that is transmissible from mixed infections with pea mosaic virus 204-1. Phytopathology 80: 268-272.

Hovinen, S. 1988. Breeding of a protein pea ideotype for Finnish conditions. J. Agric. Sci. Finl. 60: 1-72. 
- 1990. Palkokasvit: herne. In: Siemenjulkaisu 1990. Osuuskunta Hankkija, Tuusula. p. 52-58.

Hull, R. \& Davies, J. W. 1992. Approaches to nonconventional control of plant virus diseases. Critical Rev. PI. Sci. 11: 17-33.

Jayasena, K. W. \& Randles, J. W. 1985. The effect of insecticides and a plant barrier row on aphid populations and the spread of bean yellow mosaic potyvirus and subterranean clover red leaf luteovirus in Vicia faba in South Australia. Ann. Appl. Biol. 107: 355-364.

Jones, R. T. \& Diachun, S. 1977. Serologically and biologically distinct bean yellow mosaic virus strains. Phytopathology 67: 831-838.

KIELPINSKI, M. \& BLIXT, S. 1982. The evaluation of the "afila" character with regard to its utility in new cultivars of dry pea. Agri Hortique Genet. 40: 51-74.

Kujala, V. 1953. Felderbse, bei welcher die ganze Blattspreite in Ranken umgewandelt ist. Arch. Soc. Zool. Bot. Fenn. 8: 4445.

Marx, G. A. \& Provvidenti, R. 1979. Linkage relations of mo. Pea Newsl. 11: 28-29.

Provvidenti, R. 1991. Bean yellow mosaic. In: Hall, R. (ed.). Compendium of Bean Diseases. Am. Phytopathol. Soc., St. Paul, USA. p. 4647.

RedDick, B. B. \& BarnetT, O. W. 1983. A comparison of three potyviruses by direct hybridization analysis. Phytopathology 73: 1506-1510.

Roberts, I. M. \& Harrison, B. D. 1979. Detection of potato leaf roll and potato mop-top viruses by immunosorbent electron microscopy. Ann. Appl. Biol. 93: 289-297.

Schmidt, H. E. \& ZobrwalsKi, S. 1984. Determination of pathotypes of bean yellow mosaic virus using Phaseolus vulgaris L. as a differential host. Arch. Phytopathol. Pflanzenschutz 20: 95-96.

Scott, S. W., Mcl.aughlin, M. R. \& Ainsworth, A. J. 1989. Monoclonal antibodies produced to bean yellow mosaic virus, clover yellow vein virus, and pea mosaic virus which cross-react among the three viruses. Arch. Virol. 108: 161-167.

Steel, R. G. D. \& Torrie, J. H. 1981. Principles and Procedures of Statistics. A Biometrical Approach. McGrawHill, New York. 633 p.

TAPIO, E. 1970. Virus diseases of legumes in Finland and in the Scandinavian countries. Ann. Agric. Fenn. Ser. Phytopathol. 9: 1-97.

Winter, S. \& Nienhaus, F. 1989. Identification of viruses from European beech (Fagus sylvatica L.) of declining forests in Northrhine-Westfalia (FRG). Eur. J. Forest Pathol. 19: 111-118.

\section{Manuscript received December 1992}

Jari Valkonen

Department of Plant Production

P.O. Box 27, Viikki

FIN-00014 University of Helsinki, Finland 


\title{
SELOSTUS
}

\section{Kolmen pavun keltamosaiikkivirusrodun oireet ja pitoisuus kahdeksassa hernelajikkeessa}

\author{
JARI VALKONEN
}

Helsingin yliopisto

Anttilan kasvinjalostuskoetilan (aiemmin Hankkijan kasvinjalostuslaitos) koekentiltä kerätyistä hernenäytteistä eristettiin pavunkeltamosaiikkiviruksen herneenmosaiikkirotu (BYMV-Ps) ja härkäpapunäytteistä papurotu (BYMV-Vf). Virusten ja virusrotujen määritys perustui testikasvien oireisiin, elektronimikroskopialla havaittuun virushiukkasten kokoon ja muotoon, virusten härkäpavun epidermissolukon tumissa muodostamien inkluusiokappaleiden morfologiaan ja virusten reagointiin vasta-aineiden kanssa serologisissa testeissä. Tanskasta saatu Gladioluksesta eristetty BYMV-isolaatti (BYMV-G) osoittautui testeissä omaksi rodukseen.

BYMV-roduilla inokuloitiin kahdeksan hernelajiketta, joista Helka, Hovi, Pika ja Tammi olivat Hankkijan 1980-luvulla kauppaan laskemia afila-tyyppisiä (puolilehdettömiä) lajikkeita, Kalle 1950-luvulla ja Hemmo 1980-luvulla kauppaan tulleita perinteisen lehtityypin omaavia lajikkeita, sekä Solara afila-tyyppinen ja Proco perinteisen lehtityypin omaa- va Suomessa yleisesti viljeltävä hollantilainen hemelajikke. Kaikki BYMV-rodut infektoivat kaikki testatut hernelajikkeet. BYMV-Ps aiheutti herneissä voimakkaat keltakirjo-oireet ja BYMV-Vf viherkirjo-oireita, mutta BYMV-G aiheutti vain lievää viherkirjoa tai selkeäsuonisuutta. Saman virusrodun pitoisuus vaihteli lajikkeesta toiseen, mutta viruspitoisuus ja oireiden voimakkuus eivät korreloineet.

Tutkimus osoitti, että suomalaisten hernelajikkeiden BYMV-kestävyys ei ole kehittynyt 1960-luvulla tehtyjen tutkimusten jälkeen. BYMV ja erityisesti sen herneenmosaiikkirodut aiheuttavat merkittäviä satotappioita hernelajikkeissa, jotka ovat virukselle alttiita. Sen vuoksi useissa ulkomaisissa herneenjalostusohjelmissa BYMV-kestävyyden tuottavien geenien siirtoa uusiin jalosteisiin on tehty rutiininomaisesti 1960-luvulta asti. Virustautikestävyyden lisääminen parantaisi todennäköisesti suomalaisten hernejalosteiden kilpailukykyä ulkomaisilla markkinoilla. 